Ecology

\title{
An incidental case of gastric pseudomyiasis in Canis latrans (Carnivora: Canidae) by a rabbit bot fly Cuterebra sp. (Diptera: Oestridae)
}

\section{Un caso incidental de pseudomyiasis gástrica en Canis latrans (Carnivora: Canidae) por el tórsalo de conejo Cuterebra sp. (Diptera: Oestridae)}

\author{
Nora Lara-Lagunes ${ }^{\mathrm{a}}$, Santiago Jaume-Schinkel ${ }^{\mathrm{a}, \mathrm{b}}$, Sergio Ibáñez-Bernal ${ }^{\mathrm{b}, *}$ \\ ${ }^{a}$ Facultad de Biología, Universidad Veracruzana, Campus Xalapa, Circuito Presidentes, Zona Universitaria, 91090 Xalapa, Veracruz, Mexico \\ ${ }^{\mathrm{b}}$ Instituto de Ecología, A.C., Red Ambiente y Sustentabilidad, Carretera Antigua a Coatepec Núm. 351, El Haya, 91070 Xalapa, Veracruz, Mexico
}

Received 21 January 2016; accepted 24 January 2017

Available online 3 May 2017

\begin{abstract}
An incidental case of gastric pseudomyiasis in the coyote Canis latrans by a rabbit bot fly Cuterebra sp. is documented. In a coyote scat not entirely solid but somewhat watery and surrounded by mucous in the municipality of Perote, state of Veracruz, 2 myiasigenous fly larvae of the family Oestridae were found. Specimens were studied in the laboratory and found to correspond to a Cuterebra species of the buccata species-group, of which their normal hosts are hares and rabbits (Lagomorpha). Their characteristics are similar to those described for Cuterebra buccata, but the level of taxonomic knowledge of the larval stage of this family does not permit a confident identification to species. The coyote scat from which the bot fly larvae were recovered indicates that damage in the digestive tract of rabbit-predators may have serious consequences in individuals, and an increment in the abundance of these flies may favor a health problem that diminishes the life quality, not only for normal hosts, but also for their predators.
\end{abstract}

(C) 2017 Universidad Nacional Autónoma de México, Instituto de Biología. This is an open access article under the CC BY-NC-ND license (http://creativecommons.org/licenses/by-nc-nd/4.0/).

Keywords: Mexico; Parasitism; Parasitic insects; Brachycera; Lagomorpha

\section{Resumen}

Se documenta el hallazgo de un caso incidental de pseudomiasis gástrica en el coyote Canis latrans causado por el tórsalo de conejo Cuterebra sp. En una deyección de coyote con evidencias de diarrea y sangrado hallada en el municipio de Perote, estado de Veracruz, se encontraron 2 larvas de mosca miasígenas de la familia Oestridae. Los ejemplares fueron estudiados en el laboratorio y correspondían a una especie de Cuterebra del grupo buccata, cuyos hospederos normales son liebres y conejos (Lagomorpha). Sus características coinciden con la descripción de Cuterebra buccata, pero el grado de conocimiento taxonómico del grupo en etapa larval no permite asegurar la identidad de la especie. La deyección del coyote de donde los tórsalos fueron obtenidos indica que el daño en el aparato digestivo de depredadores de conejos puede tener graves consecuencias en los individuos, y un aumento en la abundancia de estas moscas puede favorecer problemas de salud que deterioran la calidad de vida no solo de los hospederos normales, sino también de sus depredadores.

(C) 2017 Universidad Nacional Autónoma de México, Instituto de Biología. Este es un artículo Open Access bajo la licencia CC BY-NC-ND (http://creativecommons.org/licenses/by-nc-nd/4.0/).

Palabras clave: México; Parasitismo; Insectos parásitos; Brachycera; Lagomorpha

\section{Introduction}

* Corresponding author.

E-mail address: sergio.ibanez@inecol.mx (S. Ibáñez-Bernal).

Peer Review under the responsibility of Universidad Nacional Autónoma de México.
The term Myiasis, from Greek $\mu v i \tilde{\alpha}$ (myia), "fly"; - $-\omega \sigma \iota \zeta$ (osis), "state, abnormal condition, or action", is a medical descriptive term that refers to the invasion or infestation of the 
body of vertebrates by fly (dipterous) larvae. Although nearly all cases of myiasis are produced by parasitic flies, there are cases in which free-living flies can invade accidentally the body or cavities of vertebrates for some time, but not necessarily complete their development. Historically and in general, myiasis cases have been classified by 2 systems. Patton's classification (James, 1947; Patton, 1921) divided myiasis-producing Diptera into 3 groups according to the grade of dependence of the invasive fly with a vertebrate: specific myiasis-producing Diptera or obligate parasites, semispecific myiasis-producing flies or facultative parasites, and accidental myiasis-producing flies (in the case of body invasion by free-living species that commonly cannot complete their development); in a strict sense, the last of these 3 possibilities is not a symbiotic relationship, and for this reason Zumpt (1965) called these cases pseudomyiasis. Bishopp's classification, modified by James (1947) and later by others (e.g., Hall \& Smith, 1993), takes into account the part of the vertebrate body affected by fly larvae, considering cutaneous myiasis, body-cavity, and also accidental myiasis, subdivided into categories according to the affected body zone of the host.

Species of about 16 families of Diptera have been recorded as myiasis producers (Zumpt, 1965), but only Oestridae including the subfamilies Cuterebrinae, Gasterophilinae, Dermatobiinae, and Oestrinae, according to the classificatory arrangement of Pape (2001) and Pape, Blagoderov, and Mostovski (2011), a few Calliphoridae, and a few Sarcophagidae are obligate parasites of vertebrates in the larval stage (Guimarães, Papavero, \& do Prado, 1983).

Cuterebrinae Brauer, 1863 was recognized for many years at the family rank, and still is by many authors (e.g., Papavero \& Guimarães, 2009). It includes 2 genera (Dermatobia Brauer, 1861, and Cuterebra Clark, 1815, e.g., Pape, 2001; Pape \& Thompson, 2013) or 6 genera (Andinocuterebra Guimarães, 1984, Cuterebra, Dermatobia, Metacuterebra Bau, 1929, Pseudogametes Bischoff, 1900, and Rogenhofera Brauer, 1863), according to Papavero and Guimarães (2009), with 14 species of Cuterebra, 1 species of Dermatobia, and 1 species of Metacuterebra (considered as a synonym of Cuterebra by Pape \& Thompson, 2013) known in Mexico (Papavero \& Guimarães, 2009).

The adult bot flies (Diptera: Oestridae) are large, robust flies with reduced or atrophied mouthparts, small antennae and a pilose, bristleless body that resembles honey or bumble bees with body color blackish, yellowish, or metallic blue (Pape, 2010). All oestrid fly larvae are obligate parasites of mammals, but only the genus Cuterebra parasitizes rodents and lagomorphs. Third instar larvae of Cuterebra are apparently unique among other oestrids for being almost entirely encrusted with small flattened plate-like spines; these spines are a synapomorphic character of the genus (Wood, 1987).

Larvae of Cuterebra spp. develop normally in skin furuncles or warbles of rodents and lagomorphs (Catts, 1982), but some cases of cuterebrid cutaneous myiasis on different hosts have been recorded (Sabrosky, 1986; Slansky, 2007). Only the report of Scott (1943) mentioned the case of a red fox Vulpes vulpes (Linnaeus) in which a bot fly larva produced gastric myiasis as it passed in feces with the remains of the previously parasitized prey, a similar condition to the case we report here. There are relatively few reports in Mexico of Cuterebra, nearly all included in Guimarães (1967), Sabrosky (1986), and Papavero and Guimarães (2009). A few records have been published since then, a Cuterebra sp. in Ototylomys phyllotis by Manrique-Saide, Hernández-Betancourt, and Quintero (2000), and a Cuterebra sp. in Sylvilagus floridanus by Bravo and Hernández-Ortiz (2016).

\section{Materials and methods}

Tenextepec belongs to the municipality of Perote, Veracruz. It is located in the semiarid zone near the state of Puebla $\left(19^{\circ} 29^{\prime} 2^{\prime \prime}\right.$ $\mathrm{N}, 97^{\circ} 15^{\prime} 50^{\prime \prime} \mathrm{W}$ ), at an altitude of $2520 \mathrm{~m}$. Annual temperature varies between $6^{\circ} \mathrm{C}$ and $11^{\circ} \mathrm{C}$, and the average annual precipitation is about $700 \mathrm{~mm}$. This area presents a great number of habitats, from pine forest to desert scrub; the natural vegetation is characterized by being composed almost entirely of bushes with rigid leaves. The great diversity of ecosystems allows the presence of a high number of animals such as reptiles, birds, and small and medium mammals. Some of the most representative species of reptiles are rattlesnakes, and horned lizards. Also, there are owls, sparrow hawks, and migrating birds. The mammals include several species of bats and mice, as well as rabbits, hares, terrestrial squirrels, wild cats, foxes, and coyotes.

On September $2^{\text {nd }}, 2015$, during the 5th month sampling for the thesis project: "Feeding habits of Coyote (Canis latrans Say, 1823) in Tenextepec, Perote, Veracuz" performed by the senior author, near the 8 th $\mathrm{km}$ of the $10 \mathrm{~km}$ transect, one peculiar coyote scat was collected and marked as the 13th sample because it looked not entirely solid but kind of watery and surrounded by mucous. In it, 2 larvae that could not be identified in the field were found; the next sample marked as the 14th also had similar appearance but it contained blood and was assumed to be from the same individual. Further analysis in the Laboratory of Wildlife, Universidad Veracruzana, showed us that the scat contained hairs. Processing these hairs with pith and flake methods showed that it was hair of a small mammal of the order Lagomorpha. The 2 larvae recovered from the feces were put in a jar with the purpose of obtaining the adult, but evidently they were dead from the beginning. After a few days they were preserved in $70 \%$ ethanol. Specimens were covered with a mass of mammalian hair that had to be removed to observe their characteristics. Hairs from the scat and directly obtained from the larvae were bleached in 30 volumes of hydrogen peroxide for 1 hour (Quadros \& Monteiro-Fhilo, 2006), then identified following Monroy-Vilchis and Rubio-Rodríguez (2003). Larvae were studied in the facilities of Red Ambiente y Sustentabilidad, Instituto de Ecología A.C., Xalapa, Veracruz (INECOL). One larva was cut transversely into 2 parts and cleared with hot $10 \% \mathrm{NaOH}$ solution, and the cephalopharyngeal apparatus dissected. Photographs of Fig. 1 were rendered with a Canon 40D and a $100 \mathrm{~mm}$ macro lens, whereas Figs. 2 and 3 were obtained using a Nikon SMZ800 stereomicroscope equipped with a Nikon camera. Fig. 6 was obtained with a Nikon Eclipse 50i and photographed with a Nikon camera. Figs. 2, 3, and 6 were processed 


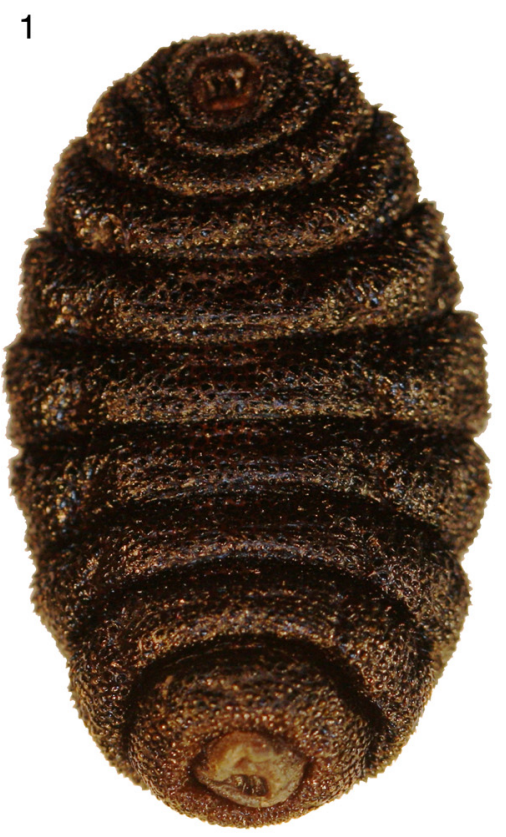

2

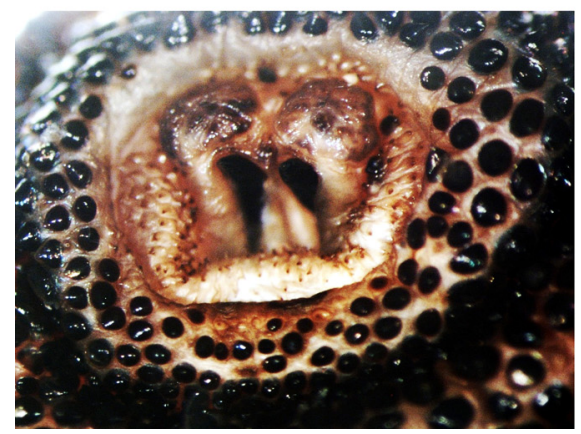

$1.0 \mathrm{~cm}$

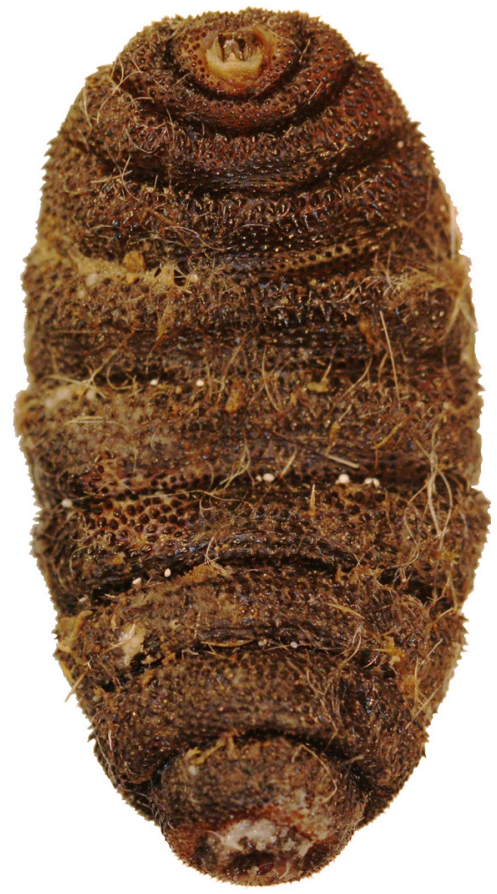

3

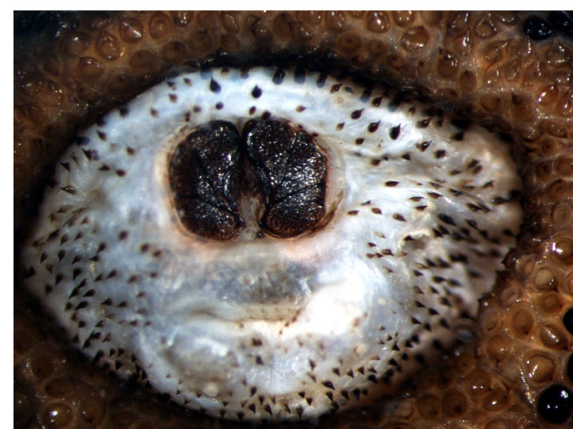

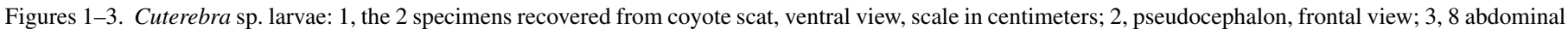
segment, posterior view (Photographs: Sergio Ibáñez-Bernal).

with NIS-Elements F v. 3.2. Drawings were rendered with the aid of a Nikon drawing tube fitted to the same stereomicroscope.

\section{Results}

Both third instar larvae evidently correspond to the same species. Larvae have a small difference in size (1 larva with $28 \mathrm{~mm}$ of length and $16 \mathrm{~mm}$ of maximum width at the third abdominal segment, and the other larva with $26 \mathrm{~mm}$ of length and $16 \mathrm{~mm}$ of maximum width at the third abdominal segment), but this is probably due to differences in contraction of the body segments. The body is oval, cream-reddish in ground color with spine-like platelets nearly black, except the cephalic and eighth abdominal segment which are more membranous and pale cream (Fig. 1). The pseudocephalum has 2 rounded tubercula in which the antennae and maxillae originate, and smooth, small, single spines around the buccal opening. The cephalopharyngeal skeleton (Fig. 4) bears black mandibles, which are smooth, hirsute, evenly curved, and apically sharpened, the ventral arch is a broad structure at the base that slightly projects ventrally (Fig. 4, mnd). The hypopharyngeal sclerite (Fig. 4, hph) is articulated anteriorly to the mandibles and posteriorly to the tentopharyngeal sclerites, which have a basal dark-brown median region and the rest are colorless. The expanded and colorless dorsal cornua (Fig. 4, dco) are apparently separated from the colorless ventral cornua (Fig. 4, vco) at the point of articulation with the hypopharyngeal sclerite (Fig. 4, hph). The ventral cornua are about one-half the length and width of the dorsal cornua, having an ample rounded posterior margin in lateral view.

The 3 thoracic segments are each covered anteriorly by simple spines, which have smooth margins. On each segment, the simple conic spines are directed posteriorly in the anterior half and, thereafter, are forwardly directed. The first 6 abdominal segments bear one-pointed spines distributed like those of the thoracic segments. Spines with smooth margins cover the seventh abdominal segment, whereas the eighth abdominal segment has similar but smaller spines with 1 tip. The circular spiracle aperture is well defined (Fig. 3). Each spiracular plate is bright orange and bears 3 interrupted sectors of intertwined serpentine slits (Fig. 5). Each of the anal tubercles has a small plate, 
4



5

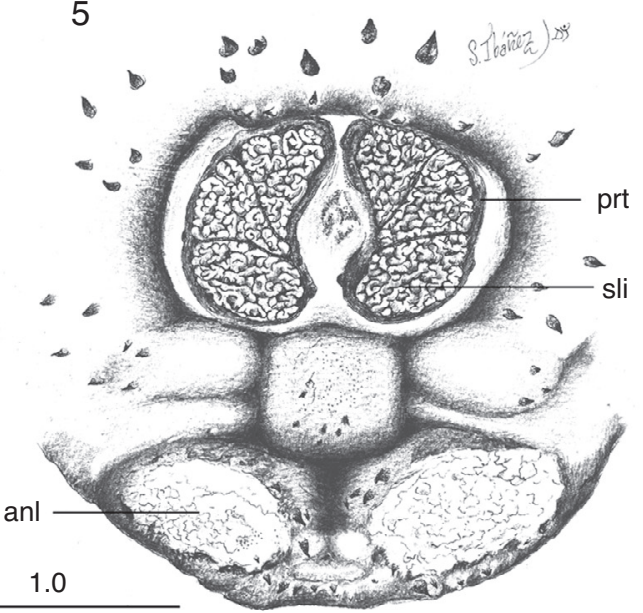

Figures 4 and 5. Cuterebra sp. larvae: 4, cephalopharyngeal skeleton, lateral view; 5, 8 abdominal segment, posterior view. Abbreviations: anl: anal lobe; dco: dorsal cornus; eso: esophagous; hph: hypopharingeal sclerite; mnd: mandible; prt: peritreme; sli: serpentine slits; vco: ventral cornus. Scales in millimeters (Drawings: Sergio Ibáñez-Bernal).

\subsection{5}

6

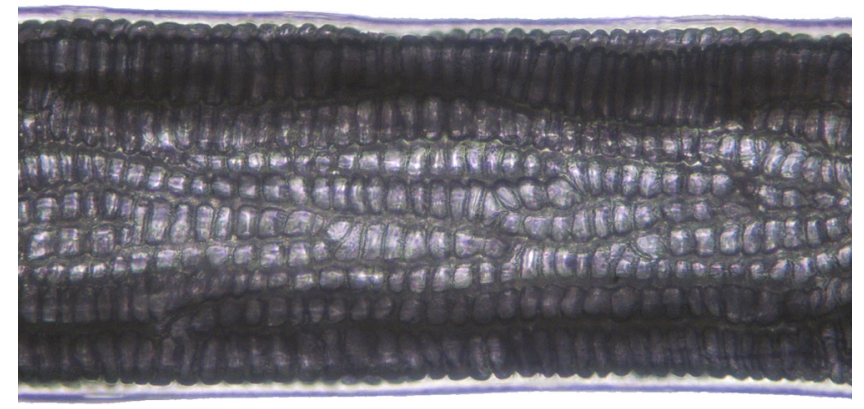

Figure 6. Sylvilagus cunicularius hair medulla, middle section of hair (Photograph: Sergio Ibáñez-Bernal).

and the anus is anteriorly and posteriorly bordered by thorn-like one-pointed spines.

On the other hand, the hairs present continuous and nodose medulla, with cells ordered in columns (Fig. 6) corresponding to the order Lagomorpha. The hairs were about $25 \mathrm{~mm}$ of total length, with cells arranged into 6-8 columns in the widest portion, matching with the hair description of Monroy-Vilchis and Rubio-Rodríguez (2003) for Sylvilagus cunicularius (Waterhouse, 1848).

\section{Discussion}

More than 70 species of cuterebrids have been described, but immature stages remain poorly known (Leite \& Williams, 1997). Sabrosky (1986) classified the North American species of Cuterebra in 4 groups, based principally on the adult characters of the species, but with a strong correlation with type of hosts and larval characters. Two groups (americana and fontiniella) are related with Rodentia as hosts and have larvae with some body spines that are plate-like with more than 1 point [imbricated scales of Austen (1895) and Townsend (1897)], whereas the other 2 (buccata and cuniculi groups) use Lagomorpha as hosts and larvae have the majority of body spines conical, each with only 1 point [spur-like plates of Townsend (1897)]. As the larvae reported here have conic simple spines, we deduce that the Canis latrans prey was a lagomorph, and the bot fly specimens belong to the buccata or cuniculi species groups. This was supported by the surrounding hair layer on their body, which was removed, bleached, measured, and fixed on a microscope slide for further analysis.

Of the 14 species of Cuterebra (sensu Guimarães \& Papavero, 2009) historically recorded in Mexico, only Cuterebra buccata (Fabricius, 1777), Cuterebra lepusculi Townsend, 1897, and Cuterebra princeps (Austen, 1895), all belonging to the buccata species group, have larvae with the characteristics seen in the 2 specimens we report. Moreover, considering the known geographic distribution of these species, it is quite probable that our specimens correspond to $C$. buccata or C. lepusculi, since C. princeps is distributed in southwestern USA (Arizona) and northwestern Mexico (Sonora), a biogeographic province very far and different from the area of our finding (Morrone, 2005). Characters observed in the 2 larvae reported in this work correspond well with the description of $C$. buccata by Knipling and Brody (1940). Moreover, this species has a wide range of distribution, occurring from North Dakota to New Hampshire, south to Texas and Florida, and in New Mexico and Arizona, in the USA, and extending to Mexico, Guatemala, and Honduras (Sabrosky, 1986). Rearing procedures are needed as Cuterebra taxonomy requires adult specimens to confirm the species.

Slansky and Kenyon (2003) summarized the information on the biology of Cuterebra and provided an excellent revision of the clinical signs on the rodent and lagomorph hosts. Parasitic density normally ranges from 1 to 3 , but sometimes a range from 5 to 10 has been recorded. An increment in the bot fly density may be due to the individual health quality of the host, but also could be a result of a decrease in the host population abundance, an increment of the botfly population, or both. Levels of bot fly parasitism could be good indicators of the host population 
abundance and an indicator of ecosystem health. As mentioned by Slansky and Kenyon (2003), an increment in bot fly density not only affects health by the number of warbles, but also can produce lethargy and secondary infections that reduce the individual life quality and as consequence the host population fitness. An imbalance of the bot fly and lagomorph populations would not stop here, as evidently it has consequences on the predator populations. The indirect effect of bot fly infested prey for the regular predators of lagomorphs has not been adequately documented, but our evidence indicates that bot fly parasitism has deleterious effects on predators of rabbits, some of which are probably threatened species. Bot fly larvae pass through the digestive tract of the predator practically intact, although dead, due to the thick, strong, and hard cuticle, producing damage with their body spines in the gastric tract epithelium, as was seen in the coyote scats that were not entirely solid but somewhat watery, surrounded by mucous and with blood traces. Internal injury of the digestive tract can cause susceptibility to secondary infections or can affect the assimilation of nutrients. This is the first report of indirect bot fly myiasis in Canis latrans, and after the report of a case in the red fox of Scott (1943), the second referring to the indirect effects of bot fly parasitism in predators of infested normal hosts. In addition, this is the first report of Sylvilagus canicularius as host of a Cuterebrid species.

\section{Acknowledgements}

This work is part of the thesis project of Nora Lara-Lagunes titled "Feeding habits of Coyote (Canis latrans Say, 1823) in Tenextepec, Perote, Veracruz", Escuela de Biología, Universidad Veracruzana (UV-X), Xalapa, Veracruz, assisted in the field by Santiago Jaume Schinkel (student of UV-X). Sergio Ibáñez-Bernal was supported by the project INECOL-10816. We appreciate the kindly help of Ricardo Ayala Barajas (Instituto de Biología, UNAM, Mexico, Campus Chamela) in obtaining useful references, Salvador Guzmán Guzmán for supporting the thesis project and providing infrastructure in the Laboratorio de Fauna Silvestre, UV-X, and Felipe Aguirre Avilés for being our local guide on the field trips.

\section{References}

Austen, E. E. (1895). Further notes on Cutiterebra. On the identity of certain species described by the late Bracy Clark. Annals and Magazine of Natural History, 16, 147-155.

Bravo, E. R., \& Hernández-Ortiz, V. (2016). Myiasis of Sylvilagus floridanus by a bot fly Cuterebra species (Diptera: Oestridae) in a xeric shrub land of Central Mexico. Entomological News, 125, 374-376.

Catts, E. P. (1982). Biology of New World bot flies: Cuterebridae. Annual Review of Entomology, 27, 313-338.
Guimarães, J. H. (1967). Family Cuterebridae. In N. Papavero (Ed.), A catalogue of the Diptera of the Americas south of the United States (pp. 1-11). São Paulo: Departamento de Zoologia, Secretaria da Agricultura.

Guimarães, J. H., Papavero, N., \& do Prado, A. P. (1983). As miíases na região neotropical (Identificação, biologia, bibliografia). Revista Brasileira de Zoologia, 1, 239-416.

Hall, M. J. R., \& Smith, K. G. V. (1993). Diptera causing myiasis in man. In R. P. Lane, \& R. W. Crosskey (Eds.), Medical insects and arachnids (pp. 429-469). London: Chapman \& Hall.

James, M. T. (1947). The flies that cause myiasis in man. United States Department of Agriculture, Miscellaneous Publication, 631, 1-175.

Knipling, E. F., \& Brody, A. L. (1940). Some taxonomic characters of cuterebrine (Diptera) larvae, with larval descriptions of two species from Georgia. The Journal of Parasitology, 26, 33-43.

Leite, A. C. R., \& Williams, P. (1997). External morphology of the immature stages of Metacuterebra apicalis. Memorias do Instituto Oswaldo Cruz, Rio de Janeiro, 92, 775-783

Manrique-Saide, P., Hernández-Betancourt, S., \& Quintero, M. T. (2000). First record of Cuterebra sp. (Diptera: Cuterebridae) infection in Ototylomys phyllotis (Rodentia: Muridae). Florida Entomologist, 83, 487-488.

Monroy-Vilchis, O., \& Rubio-Rodríguez, R. (2003). Guía de identificación de mamíferos terrestres del Estado de México, a través del pelo de guardia. Toluca: Universidad Autónoma del Estado de México.

Morrone, J. J. (2005). Hacia una síntesis biogeográfica de México. Revista Mexicana de Biodiversidad, 76, 207-252.

Papavero, N., \& Guimarães, J. H. (2009). Catalogue of Neotropical Diptera. Cuterebridae. Neotropical Diptera, 11, 1-17.

Pape, T. (2001). Phylogeny of Oestridae (Diptera). Systematic Entomology, 26, $133-171$

Pape, T. (2010). Oestridae (Bot flies). In B. V. Brown, A. Borkent, J. M. Cumming, D. M. Wood, N. E. Woodly, \& M. A. Zumbado (Eds.), Manual of Central American Diptera (Vol. 2) (pp. 1305-1311). Ottawa: NRC, Research Press, National Research Council of Canada.

Pape, T., Blagoderov, V., \& Mostovski, M. B. (2011). Order Diptera Linnaeus, 1758. In Zhang Z. Q. (Ed.), Animal biodiversity: an outline of higher-level classification and survey of taxonomic richness. Zootaxa, 3148, 222-229.

Pape, T., \& Thompson, F. C. (Eds.). (2013). Systema Dipterorum, Version [1.5]. http://www.diptera.org/, accessed on 29.09.15.

Patton, W. S. (1921). Notes on the myiasis-producing Diptera of man and animals. Bulletin of Entomological Research, 12, 239-261.

Quadros, J., \& Monteiro-Fhilo, E. L. A. (2006). Coleta e preparação de pelos de mamíferos para identificação em microscopia óptica. Revista Brasileira de Zoología, 23, 274-327.

Sabrosky, C. W. (1986). North American species of Cuterebra. The rabbit and rodent botflies (Diptera: Cuterebridae). Maryland: Thomas Say Foundation, Entomological Society of America.

Scott, T. G. (1943). Some food coactions of the Northern Plains red fox. Ecological Monographs, 13, 427-479.

Slansky, F. (2007). Feline cuterebriosis caused by a lagomorph-infesting Cuterebra spp. larva. The Journal of Parasitology, 93, 959-996.

Slansky, F., \& Kenyon, L. R. (2003). Cuterebra bot fly infestation of rodents and lagomorphs. Journal of Wildlife Rehabilitation, 26, 7-16.

Townsend, C. H. T. (1897). Description of the bot-fly of the cotton-tail rabbit in New Mexico, Cuterebra lepusculi n. sp. Psyche, 8, 8-9.

Wood, D. M. (1987). Oestridae. In J. F. McAlpine, B. V. Peterson, G. E. Shewell, H. J. Teskey, J. R. Vockeroth, \& D. M. Wood (Eds.), Manual of Neartic Diptera (Vol. 2) (pp. 1147-1158). Ottawa: Research Branch Agriculture Canada.

Zumpt, F. (1965). Myiasis in man and animals in the Old World. London: Butterworths. 